\title{
EFFECTS OF DIETARY INCLUSION OF GUAR KORMA MEAL LEVELS WITH OR WITHOUT ENZYME SUPPLEMENTATION ON PERFORMANCE OF LOCAL STRAIN CHICKS (ANSHAS)
}

\author{
M.M. Nasrala; Amany H. Waly; Heba H. Habib; Hemat A. Abdel Magied; I.M.M. Assaf \\ and M.M. Ouda
}

Animal Production Research Institute, Agricultural Research Center, Dokki, Giza, Egypt.

SUMMARY

$\mathrm{T}$ This study aimed to evaluate the effect of inclusion of guar korma meal (GKM) as a partial replacement for soybean meal (SBM) in commercial local strain (Anshas) diets on growth performance, digestibility, slaughter traits and economical efficiency. The experimental period lasted for 3 months. Chicks received (GKM) at $0,2.5,5,7.5$ and $10 \%$ with or without $\beta$-mannase enzyme $\left(\right.$ Hemicell ${ }^{\circledR}$ ) supplement. Results indicated that GKM without enzyme can be used as a feed ingredient without adverse effect at level $2.5 \%$. Using GKM in levels more than $2.5 \%$ depress weight gain, feed conversion and nutrients digestibility. Addition of enzyme to the diets improve weight gain, feed conversion and nutrients digestibility of diets containing 5\% of GKM. Feed intake increased as the level of GKM in diets increased. Enzyme supplement had no effect on feed intake. Enzyme supplement could not overcome the adverse effect of GKM on nutrients digestibility only in diets contain 7.5 and $10 \%$ of GKM. Dressing percentage decreased as the level of GKM in diet increased. Addition of enzyme to the diets contain GKM improved dressing percentage. GKM can be used without enzyme addition at level $2.5 \%$ without adverse effect on dressing percentage.

From the nutritional and economical points of view, results indicated that GKM can be used as a feed ingredient at level $2.5 \%$ without enzyme supplement. When enzyme was added to the diets level of GKM can be increased up to $5 \%$ without any adverse effect.

Keywords: Guar korma meal, enzyme, performance, digestibility, carcass and economical efficiency.

\section{INTRODUCTION}

Guar Korma Meal (GKM) is a relatively inexpensive high protein meal produced as a by-product of guar gum manufacture. Guar korma meal is the main by-product of guar gum production with a protein content of approximately $380 \mathrm{~g} / \mathrm{kg}$ (Nagpal et al., 1971). It is a mixture of germs and hulls at an approximate ratio of $25 \%$ germ to $75 \%$ hull (Lee et al., 2004). Guar korma meal contains approximately 35-45\% crude protein (Nagpal et al., 1971 and Lee et al., 2004).

Guar korma meal contains 13-18\% residual galactomannan gum (Anderson and Warnick, 1964; Nagpal et al., 1971 and Lee et al., 2004). Beta-mannan, also referred to as $\beta$-galactomannan, is a polysaccharide with repeating units of mannose, with galactose or glucose, or both, often found attached to the $\beta$-mannan backbone. The solubility of $\beta$-mannan in water increases as the number of galactose molecules on the mannan backbone increases (Hsiao et al., 2006). The high amino acid content of the guar korma meal makes it a useful protein source for broilers and layers (Mishra et al., 2013). Approximately $88 \%$ of the nitrogen content in guar korma meal is true protein that makes it potentially useful as an ingredient for poultry feed (Verma and McNab (1984); Lee et al. (2003a, b) and Lee et al. (2005). Nadeem et al. (2005) reported that amino acids availability ranged from 64 to $93 \%$ for guar korma meal residual guar gum. A highly viscous galactomannan polysaccharide, is probably the primary factor responsible for the reported ill effects (Verma and McNab, 1982), although other antinutritional factors such as saponins (Curl et al., 1986) and polyphenols (Kaushal and Bhatia, 1982) have been reported to cause liver, kidney, and intestinal damage in mice and rats (Berman et al., 1995 and Diwan et al., 2000). Therefore, growth inhibition that follows the addition of guar korma meal in diet may be attributed to the residual gum content of the meal (Lee et al., 2005).

Some of the anti-nutritional agents (trypsin inhibitors, gum residue, saponins) present in guar meal limit its usage at high levels in broiler diets (Anderson and Warnick, 1964). The deleterious effects attributed to the trypsin inhibitors have been an issue of contradiction because it was reported that guar 
korma meal contained lower levels of trypsin inhibitor than processed SBM (Bochers and Ackerson, 1950 and Conner, 2002). Inclusion of guar korma meal in poultry diets reduces broiler chicken growth by 25$30 \%$ (Vohra and Kratzer, 1965). On contrary, Bochers and Ackerson (1950) believed that guar beans contain no trypsin inhibitor. Most researchers believe that gum residue, not trypsin inhibitor, causes the anti-nutritive effects of guar korma meal. Quantitation of trypsin inhibitor activity in guar beans, guar korma meal, soybeans, and soybean meal proved that less trypsin inhibitor occurs in guar korma meal than in heat-treated commercially processed soybean meal (Lee et al., 2004). Anti-nutritional components like guar gum ( $\beta$-mannan), saponins and trypsin inhibitors limit the use of guar korma meal in broiler diets (Hussain et al., 2012). However, residual gum in guar korma meal increases intestinal viscosity in chickens, which reduces growth and feed efficiency (Lee et al., 2003a).

The negative effects of adding guar korma meal on body weight and feed conversion ratio might be attributed to that guar korma meal contains 5-13\% of dry matter triterpenoid guar saponin (Hassan et al., 2007) and 13-18\% guar gum, residual galactomannan gum ( Lee et al., 2004). So, guar korma meal used in poultry diets was limited by its adverse effects on growth rate (Thakur and Pradhan, 1975a). $\beta$-mannan is considered a major anti-nutritional factor when higher levels of guar korma meal are used in poultry diets (Hussain et al., 2012).

Guar korma meal in poultry feed has been limited because of reported adverse effects, which include diarrhea, depressed growth rate, and increased mortality, when fed at relatively high levels (Verma and McNab 1982). Patel and McGinnis (1985) found that $10 \%$ seems to be the maximum acceptable rate. An inclusion rate of $2.5 \%$ untreated guar korma meal can support growth, feed consumption, feed:gain ratio, and meat yield equivalent to those of a corn-soybean meal diet (Conner, 2002). The antinutritional effects are more pronounced in young birds (Verma and McNab, 1982). The residual gum present in the hull fraction (and to a lesser extent in the germ) is thought to be the main cause of the antinutritional value of guar korma meal. The gum increases intestinal viscosity, preventing the correct mixing of digesta and their contact with digestive secretions. It also causes watery and sticky feces (Lee et al., 2009). The effects on animal performances of other antinutritional factors present in guar korma meal, notably antitrypsin inhibitors, are less certain (Lee et al., 2004). High levels of GKM in broilers diets deleteriously affect growth performance, FI, FCR and blood lipids, and the optimal level of GKM is low being 25\% (as a partial replacement for SBM) without adverse effects on growth performance, carcass traits, blood lipids or economical efficiency of broilers. (Salma et al., 2015).

Supplementing the diet with the $\beta$-mannanase enzyme improved the negative effects of the galactomannan content of guar korma meal. $\beta$-mannanase hydrolyses the galactomannan complex of guar korma meal. As a result, the guar gum induced viscosity in digesta is reduced, which increases the digestibility of starch (Zangiabadi and Torki, 2010 and Ehsani and Torki, 2010) and improves the metabolizable energy of guar korma meal. In this way, â- mannanase supplementation helps in achieving superior feed conversion and better growth performance in broilers fed guar korma meal (McNaughton $e t$ al., 1998 and Daskiran et al., 2004).

Since the germ fraction of guar korma meal contains energy, protein, methionine and phosphorus in higher levels than that in soybean meal (SBM), addition of guar korma meal as a partial replacement (< $10 \%$ ) of SBM in poultry diets may be a useful economical strategy for decreasing feed costs without any negative effects on production (Kamran et al., 2002). Jackson et al. (2004) found that $\beta$-mannanase enzyme (Hemicell) improves weight gain and feed conversion in broiler.

The objective of this study is to determine the effect of using guar korma meal (GKM) as a feed ingredient with or without $\beta$ - mannanase enzyme (Hemicell) supplement on growth performance, nutrients digestibility, some physiological parameters and economical efficiency.

\section{MATERIALS AND METHODS}

The experiment was conducted at Poultry Research Station (anshas), Animal Production Research Institute, Agriculture Research Center, Ministry of Agriculture, Egypt. Four hundred and five anshas chicks, at one day old, were randomly assigned into nine equal experimental groups (45birds each) with three replicates (15 birds each). Diets were fed from 1 day to 12 weeks. The composition and calculated analysis of the experimental diets are shown in Table (1).

All diets were formulated to be isonitrogenous (about 19\% CP) and isocaloric (about 2800ME/ kg diet). A corn-Soybean basal diet that met all the requirements recommended by Agriculture Ministry Decree (1996) was fed to birds of the control group $\left(T_{1}\right)$. Groups $T_{2}, T_{3}, T_{4}$ and $T_{5}$ are diets contain GKM as a feed ingredient without enzyme supplementation, where GKM represents $2.5,5,7.5$ and $10 \%$, replacement from SBM, respectively. While, groups $\mathrm{T}_{6}, \mathrm{~T}_{7}, \mathrm{~T}_{8}$ and $\mathrm{T}_{9}$ are diets contain GKM the same levels but with Hemicell supplements at level of $0.3 \mathrm{~g} / \mathrm{kg}$ diet. Hemicell ${ }^{\circledR}$ - HT is $\beta$ - mannanase enzyme 
witch extracted from Bacillus Lentus and obtained from Hemgen crop. U. S. A. and contain 160 million units/ $\mathrm{kg}$.

Chicks kept under the same management system, diets and water were offered to chicks' ad-libitum throughout the experimental period. Live body weight (LBW) and feed intake were recorded weekly, then body weight gain (BWG) and feed conversion were calculated. The chemical composition of dietary treatments, and excreta were done according to the methods of A.O.A.C. (1990). Three males of each treatment were used during the last week of experiment to determine the digestibility of nutrients.

At the end of the experiment, 3 birds of each treatment were randomly slaughtered to determine carcass, liver, gizzard and heart weight, then giblets and dressing percentages were calculated. The economical and the relative economical efficiency (REE) were calculated in relation to local market prices at time of the experiment.

Table (1). Composition and calculated analysis of experimental diets.

\begin{tabular}{|c|c|c|c|c|c|}
\hline \multirow{2}{*}{ Ingredients } & \multirow{2}{*}{ Control } & \multicolumn{4}{|c|}{ Diets contain GKM } \\
\hline & & $2.5 \%$ & $5 \%$ & $7.5 \%$ & $10 \%$ \\
\hline Yellow corn & 59.84 & 59.54 & 59.70 & 59.55 & 59.50 \\
\hline Soybean Meal-44\% & 24.20 & 21.60 & 18.50 & 15.10 & 12.00 \\
\hline Guar Korma Meal-50\% & 0.00 & 2.50 & 5.00 & 7.50 & 10.00 \\
\hline Wheat Bran & 8.20 & 8.60 & 9.00 & 10.01 & 10.63 \\
\hline Corn Gluten $60 \%$ & 4.00 & 4.00 & 4.00 & 4.00 & 4.00 \\
\hline Dical. Phos. & 1.53 & 1.53 & 1.53 & 1.53 & 1.53 \\
\hline Lime stone & 1.52 & 1.52 & 1.52 & 1.52 & 1.52 \\
\hline Salt & 0.37 & 0.37 & 0.37 & 0.37 & 0.37 \\
\hline Premix* & 0.30 & 0.30 & 0.30 & 0.30 & 0.30 \\
\hline DL-Methionine & 0.04 & 0.04 & 0.08 & 0.12 & 0.15 \\
\hline Total & 100 & 100 & 100 & 100 & 100 \\
\hline \multicolumn{6}{|l|}{ Calculated analysis: } \\
\hline Crude Protein (CP \%) & 18.99 & 19.16 & 19.17 & 19.12 & 19.14 \\
\hline $\mathrm{ME} \mathrm{kcal} / \mathrm{g}$ & 2800 & 2800 & 2806 & 2803 & 2804 \\
\hline Crude Fiber (CF \%) & 4.12 & 4.11 & 4.08 & 4.08 & 4.06 \\
\hline Ether extract (EE \%) & 3.05 & 3.12 & 3.20 & 3.29 & 3.38 \\
\hline Calcium $\%$ & 1.00 & 0.99 & 0.98 & 0.97 & 0.96 \\
\hline Avail. Phosphorus \% & 0.45 & 0.44 & 0.43 & 0.43 & 0.42 \\
\hline Lysine \% & 0.95 & 0.87 & 0.79 & 0.69 & 0.60 \\
\hline Methionine \% & 0.40 & 0.39 & 0.41 & 0.43 & 0.44 \\
\hline Met + Cys $\%$ & 0.73 & 0.70 & 0.70 & 0.70 & 0.69 \\
\hline Sodium $\%$ & 0.16 & 0.16 & 0.16 & 0.16 & 0.16 \\
\hline
\end{tabular}

Data obtained were statistically analyzed by the SAS program (SAS, 1996) using one-way analysis of variance (included 9 treatments), as in the following model:

$\mathrm{Yij}=\mu+\mathrm{Ti}+\mathrm{eij}$

Were Yij $=$ individual observation; $\mu=$ overall mean; $\mathrm{Ti}=$ the effect of treatments, and eij $=$ the experimental error. Differences between treatments means were separated using Duncan's (1955) new multiple range test at a probability level of 0.05 . 


\section{RESULTS AND DISCUSSION}

\section{Effect of using GKM as feed ingredient with or without Hemicell supplements on growth performance:}

Effect of using GKM as feed ingredient with or without Hemicell supplementation on growth performance are shown in Table (2). The initial value of live body weight (LBW) were nearly the same which due to the effect of randomization procedure.

Table (2). Effect of GKM replacement with or without Hemicell supplement on performance of anshas chicks.

\begin{tabular}{|c|c|c|c|c|c|}
\hline Treatments & Initial LBW & $\begin{array}{l}\text { Final weight } \\
(\mathrm{g})\end{array}$ & $\begin{array}{l}\text { Feed intake } \\
(\mathrm{g})\end{array}$ & $\begin{array}{c}\text { Body weight gain } \\
(\mathrm{g})\end{array}$ & Feed conversion \\
\hline Control & 30.00 & $993.33^{\mathrm{a}}$ & $2740.00^{c}$ & $963.33^{\mathrm{a}}$ & $2.84^{\mathrm{e}}$ \\
\hline 2.5 & 29.00 & $990.33^{\mathrm{a}}$ & $2886.67^{\mathrm{abc}}$ & $961.33^{\mathrm{a}}$ & $3.00^{\mathrm{dce}}$ \\
\hline 5.0 & 30.00 & $979.67^{\mathrm{b}}$ & $2897.33^{\mathrm{abc}}$ & $949.67^{\mathrm{b}}$ & $3.05^{\mathrm{dc}}$ \\
\hline 7.5 & 30.66 & $945.00^{\mathrm{d}}$ & $2881.33^{\mathrm{abc}}$ & $914.33^{\mathrm{d}}$ & $3.15^{\mathrm{bc}}$ \\
\hline 10.0 & 29.66 & $911.67^{\mathrm{f}}$ & $2990.00^{\mathrm{ab}}$ & $882.00^{f}$ & $3.39^{\mathrm{a}}$ \\
\hline Enz-2.5 & 30.33 & $995.00^{\mathrm{a}}$ & $2816.67^{\mathrm{bc}}$ & $964.67^{\mathrm{a}}$ & $2.92^{\mathrm{de}}$ \\
\hline Enz -5.0 & 29.33 & $993.67^{\mathrm{a}}$ & $2860.00^{\mathrm{abc}}$ & $964.33^{\mathrm{a}}$ & $2.97^{\mathrm{dce}}$ \\
\hline Enz -7.5 & 30.00 & $955.00^{c}$ & $3012.67^{\mathrm{a}}$ & $925.00^{c}$ & $3.26^{\mathrm{ab}}$ \\
\hline Enz-10.0 & 29.33 & $928.33^{\mathrm{e}}$ & $2977.00^{\mathrm{ab}}$ & $899.00^{\mathrm{e}}$ & $3.31^{\mathrm{ab}}$ \\
\hline Mean of SE & \pm 0.59 & \pm 3.21 & \pm 54.29 & \pm 3.30 & \pm 0.06 \\
\hline Probability & N.S & $<0.0001$ & 0.04 & $<0.0001$ & $<0.0001$ \\
\hline
\end{tabular}

Increasing the level of guar korma meal without Hemicell supplement overall the period of the experiment significantly decreased LBW and body weight gain (BWG). The lowest value of BWG was $882 \mathrm{~g}$ with group received $10 \%$ GKM. Whereas, there were no differences between treatments contain $2.5 \%$ guar and the control (961.33 and $963.33 \mathrm{~g}$, respectively). Diet contain GKM with enzyme increased $\mathrm{LBW}$, the best value was $964.33 \mathrm{~g}$ with group received 5\% GKM.

The negative effect of high levels of guar meal inclusion in chicken diets on chick performance is documented by several researchers and they attributed this effect to guar gum residues in guar meal. These results are in agreement with those of Kamran el al. (2002), which recorded that the birds consuming lower level of guar korma meal gained more weight than those consumed higher levels of guar meal. Also, Thakur and Pradhan (1975a); Brahma and Siddiqui (1978); Nagra et al., (1985a); Nagra et al., (1985b); Patel and McGinnis (1985); Nagra and Virk (1986); Khan (1996); Rajput et al. (1998) reported that increasing guar meal level in diet decreased BWG.

Feed intake (FI) was significantly increased with increasing GKM with or without Hemicell supplement. This result agreed with Thakur and Pradhan (1975a); Sagar et al. (1978); Gharaei et al. (2012), Mishra el al. (2013) and Mohamed (2014), while, disagree with Verma and McNab (1982); khan (1996) and Kamran et al. (2002). The increase in feed intake may be due to that GKM depressed the digestibility of starch and deprive the birds of the available energy (Edward et al., 1988), which increase the feed intake to compensate the depress in digestibility.

The results (table 2) indicate that the higher level of GKM (more than $2.5 \%$ without enzyme) depress feed conversion (FC). While, Hemicell addition to the diets that contain GKM improve FC at level 2.5 and 5\%. This result is in agreement with Thakur and Pradhan (1975a); Jackson et al., (1999), Kamran et al. (2002); Gharaei et al. (2012). Mishra el al. (2013) who found that GKM had a negative effect on FC. The improvement in FC with enzyme supplementation may be due to that GKM decrease glucose metabolism and retarded insulin secretion rates in swine (Leeds el al., 1980).

Also, GKM contains $\beta$-mannan, saponins and trypsin inhibitors that limits the use of guar meal in broiler diets. These anti-nutritional factors have been reported to depress growth in birds, but at lower levels, some of these $\beta$-mannan and saponins have positive effects on bird health and performance. $\beta$ mannan is considered a major anti-nutritional factor when higher levels of guar korma meal are used in poultry (Lee et al., 2003b; Lee et al., 2004; Lee et al., 2005 and Hussain et al., 2012). The high content of galactomanan in guar korma meal increases digesta viscosity and suppress nutrient digestibility which 
cause growth depression in broiler chicken (Almirall el al., 1995). On the other hand, guar korma meal depressed the digestibility of starch and deprives the birds of the available energy (Edward et al., 1988).

Mishra el al. (2013) reported that the residual indigestible polysaccharides, such as pectin and $\beta$ galactomanan, present in the guar korma meal increase the intestinal viscosity and inhibited the performance of broiler. Growth depression of chickens fed with guar korma meal may be overcome by treating the feed with enzymes capable to hydrolyzing it (Gharaei et al., 2012). The improvements in performance with adding enzyme may be due to that $\beta$-mannanase liberate more energy by improving the digestibility of starch (Ehsani and Torki 2010).

\section{Digestibility of nutrients}

The effect of using GKM as feed ingredient with or without Hemicell supplementation on digestibility traits are distinct in Table (3).

Table (3). Effect of GKM replacement with or without Hemicel supplementation on nutrients digestibility traits.

\begin{tabular}{lcccccc}
\hline \multicolumn{1}{c}{ Treatments } & DM & OM & CP & CF & EE & NEF \\
\hline Control & 74.87 & $80.87^{\mathrm{a}}$ & $83.81^{\mathrm{ab}}$ & $27.75^{\mathrm{a}}$ & $75.56^{\mathrm{a}}$ & 80.70 \\
2.5 & 74.91 & $80.65^{\mathrm{a}}$ & $83.73^{\mathrm{ab}}$ & $26.59^{\mathrm{a}}$ & $74.93^{\mathrm{a}}$ & 80.08 \\
5.0 & 74.53 & $79.41^{\mathrm{bcd}}$ & $81.68^{\mathrm{cd}}$ & $24.53^{\mathrm{b}}$ & $72.01^{\mathrm{b}}$ & 79.50 \\
7.5 & 71.73 & $79.08^{\mathrm{cd}}$ & $80.58^{\mathrm{de}}$ & $22.50^{\mathrm{c}}$ & $71.61^{\mathrm{b}}$ & 77.31 \\
10.0 & 71.31 & $78.83^{\mathrm{b}}$ & $79.23^{\mathrm{e}}$ & $20.73^{\mathrm{d}}$ & $70.15^{\mathrm{b}}$ & 79.77 \\
Enz-2.5 & 75.99 & $80.92^{\mathrm{a}}$ & $84.29^{\mathrm{a}}$ & $27.73^{\mathrm{a}}$ & $75.87^{\mathrm{a}}$ & 80.09 \\
Enz -5.0 & 74.39 & $80.52^{\mathrm{ab}}$ & $82.56^{\mathrm{bc}}$ & $26.72^{\mathrm{a}}$ & $75.28^{\mathrm{a}}$ & 79.11 \\
Enz -7.5 & 72.29 & $80.40^{\mathrm{ab}}$ & $81.95^{\mathrm{cd}}$ & $22.28^{\mathrm{cd}}$ & $72.09^{\mathrm{b}}$ & 79.17 \\
Enz-10.0 & 72.29 & $80.11^{\mathrm{abc}}$ & $81.09^{\mathrm{cd}}$ & $22.22^{\mathrm{cd}}$ & $71.88^{\mathrm{b}}$ & 78.62 \\
Mean of SE & \pm 3.34 & $\pm 0.37^{\mathrm{c}}$ & \pm 0.50 & \pm 0.54 & \pm 0.64 & \pm 3.73 \\
probability & $\mathrm{N} . \mathrm{S}$ & 0.003 & $<0.0001$ & $<0.0001$ & 0.05 & N.S \\
\hline
\end{tabular}

$a, b, \ldots=$ Means in the same column with different superscripts, differ significantly $(P<0.05)$.

N.S= non significant.

The results indicate that the increasing level of GKM decreased the digestibility of all nutrients, while, adding $\beta$-mannanase enzyme to the diets contain GKM improve all nutrients digestibility. Using guar korma meal in diets at level $2.5 \%$ did not have any adverse effect on digestibility of all nutrients. The digestibility coefficient of the diets contain high level of GKM (7.5 and 10\%) with Hemicell supplements were less than the control group. These results are in accordance with the finding of Zangiabadi and Torki (2010); Ehsani and Torki (2010) and Hussain et al. (2012). The improvement in nutrients digestibility with enzyme supplement may be due to that $\beta$-mannanase hydrolyses the galactomannan complex of guar meal. As a result the guar gum induced viscosity in digesta is reduced, which increases the digestibility of starch (Zangiabadi and Torki, 2010 and Ehsani and Torki, 2010) and improves the metabolizable energy of guar korma meal. In this way, $\beta$-mannanase supplementation helps in achieving superior feed conversion and better growth performance in broilers fed with guar korma meal (McNaughton et al., 1998 and Daskiran et al., 2004).

\section{Slaughter traits}

The effect of experimental diets on slaughter traits are represented in Table (4). Using GKM as a feed ingredient without enzyme supplement significantly decreased the percentage of carcass and heart. While, gizzard and liver was insignificantly decreased. Carcass, liver, gizzard and heart were increased with adding Hemicell. The results indicate that dressing percentage decreased with increasing the level of GKM (without enzyme) in diet, but using GKM at level 2.5\% have no adverse effect on dressing. Hemicell supplement to the diet improves the percentage of dressing percent. The higher value of dressing percentage was 79.18 for group received 2.5\% GKM with Hemicell supplement. These results are in agreement with Thakur and Pradhan (1975b); Karman et al. (2002) and Mishra el al. (2013). 
Egyptian J. Nutrition and Feeds (2015)

Table (4). Effect of GKM replacement with or without Hemicell supplement on slaughter traits (\%).

\begin{tabular}{lcccccc}
\hline Treatments & Carcass & Liver & Gizzard & Heart & Giblits & Dressing \\
\hline Control & $64 .^{59 \mathrm{a}}$ & 7.03 & 6.17 & $1.29 \mathrm{a}$ & $14.48^{\mathrm{a}}$ & $79.08 \mathrm{ab}$ \\
2.5 & $63.55^{\mathrm{ab}}$ & 6.77 & 6.00 & $1.30^{\mathrm{a}}$ & $14.06^{\mathrm{ab}}$ & $77.61 \mathrm{bc}$ \\
5.0 & $61.99^{\mathrm{cd}}$ & 7.16 & 5.72 & $1.15^{\mathrm{b}}$ & $14.04^{\mathrm{ab}}$ & $76.03 \mathrm{~d}$ \\
7.5 & $61.22^{\mathrm{d}}$ & 5.92 & 5.53 & $1.12^{\mathrm{b}}$ & $12.56^{\mathrm{b}}$ & $73.78 \mathrm{e}$ \\
10.0 & $59.20^{\mathrm{e}}$ & 5.88 & 5.57 & $1.03^{\mathrm{b}}$ & $12.48^{\mathrm{b}}$ & $71.68 \mathrm{f}$ \\
Enz-2.5 & $64.53^{\mathrm{a}}$ & 7.03 & 6.31 & $1.30^{\mathrm{a}}$ & $14.65^{\mathrm{a}}$ & $79.18 \mathrm{a}$ \\
Enz -5.0 & $64.22^{\mathrm{a}}$ & 7.06 & 5.61 & $1.15^{\mathrm{b}}$ & $13.82^{\mathrm{ab}}$ & $78.04 \mathrm{ab}$ \\
Enz -7.5 & $62.66^{\mathrm{bc}}$ & 6.84 & 5.84 & $1.15^{\mathrm{b}}$ & $13.83^{\mathrm{ab}}$ & $76.50 \mathrm{~cd}$ \\
Enz-10.0 & $61.90^{\mathrm{cd}}$ & 6.23 & $5.18^{\mathrm{b}}$ & $1.08^{\mathrm{b}}$ & $12.49^{\mathrm{b}}$ & $74.39 \mathrm{e}$ \\
Mean of SE & \pm 0.39 & \pm 0.37 & \pm 0.28 & \pm 0.04 & \pm 0.04 & \pm 0.51 \\
Probability & $<0.0001$ & N.S & N.S & 0.001 & 0.03 & $<0.0001$ \\
\hline
\end{tabular}

$a, b, \ldots=$ Means in the same column with different superscripts, differ significantly $(P<0.05) . N . S=$ non significant .

\section{Economical efficiency}

The effects of dietary replacement of GKM with or without Hemicell supplement on economical efficiency are shown in Table (5). The results indicate that the chicks fed control diet, diet containing 5 and $2.5 \%$ GKM with Hemicell supplement recorded the highest values of relative economical efficiency $(100,99.93$ and $99.45 \%$ respectively), while those fed $10 \%$ GKM with or without enzyme and $7.5 \%$ GKM with enzyme recorded the lowest REE value (91.89, 90.90 and 89.14\%, respectively). This finding is in agreement with Salma et al. (2015), who reported that the addition of GKM as a partial replacement for SBM as a protein source in poultry diet may be useful economical strategy for decreasing feed cost. The low price of GKM can be useful in increasing the percentage of REE only when GKM is used in 5\% with Hemicell supplement, accordingly, Hemicell supplement can overcome the adverse effect of GKM.

Table (5). Effect of using GKM with or without Hemicell supplement on economical efficiency

\begin{tabular}{|c|c|c|c|c|c|c|c|c|c|}
\hline Treatments & $\begin{array}{c}\text { Body } \\
\text { Weight } \\
\text { Gain(g) }\end{array}$ & $\begin{array}{l}\text { Feed } \\
\text { Intake } \\
(\mathrm{g})\end{array}$ & $\begin{array}{l}\text { Total } \\
\text { feed } \\
\text { coast/ } \\
\text { chick } \\
\text { (LE) }\end{array}$ & $\begin{array}{l}\text { Body } \\
\text { Weight } \\
\text { Gain } \\
(\mathrm{kg})\end{array}$ & $\begin{array}{c}\text { Feed } \\
\text { Coast/ } \\
\mathrm{kg} \\
\text { Weight } \\
\text { gain }\end{array}$ & $\begin{array}{c}\text { Total } \\
\text { Revenue/ } \\
\text { Kg } \\
\text { weight } \\
\text { Gain (LE) }\end{array}$ & $\begin{array}{c}\text { Net } \\
\text { revenue } \\
\text { / chick } \\
(\mathrm{LE})^{2}\end{array}$ & $\begin{array}{l}\text { Economic } \\
\text { Efficiency }^{3}\end{array}$ & $\begin{array}{c}\text { Relative } \\
\text { Economic } \\
\text { Efficiency } \\
\%^{4}\end{array}$ \\
\hline Control & 963.33 & 2740.00 & 6.86 & 0.96 & 7.12 & 24.08 & 17.22 & 2.51 & 100.00 \\
\hline 2.5 & 961.33 & 2886.67 & 6.96 & 0.96 & 7.24 & 24.03 & 17.07 & 2.45 & 97.65 \\
\hline 5.0 & 946.66 & 2897.33 & 6.86 & 0.95 & 7.23 & 23.74 & 16.88 & 2.46 & 97.99 \\
\hline 7.5 & 914.33 & 2881.33 & 6.69 & 0.91 & 7.31 & 22.86 & 16.17 & 2.42 & 96.31 \\
\hline 10.0 & 882.00 & 2990.00 & 6.72 & 0.88 & 7.62 & 22.05 & 15.33 & 2.28 & 90.90 \\
\hline Enz-2.5 & 964.67 & 2816.67 & 6.90 & 0.96 & 7.15 & 24.12 & 17.22 & 2.50 & 99.47 \\
\hline Enz -5.0 & 964.33 & 2860.00 & 6.87 & 0.96 & 7.13 & 24.11 & 17.24 & 2.51 & 99.93 \\
\hline Enz -7.5 & 925.00 & 3012.60 & 7.14 & 0.93 & 7.72 & 23.13 & 15.98 & 2.24 & 89.14 \\
\hline Enz-10.0 & 899.00 & 2977.00 & 6.80 & 0.90 & 7.56 & 22.48 & 15.68 & 2.31 & 91.89 \\
\hline
\end{tabular}

Total price for feeds was calculated according to the price of different ingredients available in ARE.

${ }^{1}$ The price was calculated due to the local market the price of one Kg of enzyme (120 LE) and one ton of Guar korma meal (1900 LE) and price of one Kg live weight was 25 LE.

$2 \mathrm{Net}$ revenue $=$ total revenue/ chick- total feed cost.

3 Economic efficiency $=$ net revenue/ total feed coast.

${ }^{4}$ Relative economic efficiency of the control, assuming that the relative E1 of the control $(T 1)=100$

\section{CONCLUSION}

It can be concluded from the previous results that GKM could be applied at $2.5 \%$ without enzyme and up to 5\% with enzyme supplement (Hemicell) in Egyptian local strain (anshas) diets without adverse effect on growth performance, digestibility of nutrients, dressing percentage and economical efficiency. 


\section{REFERENCES}

Agriculture Ministry Decree (1996). The standard properties for ingredients, feed additives and feed manufactured for animal and poultry. El Wakaee El Masria, No. 192 (1997) P. 95 Amirria Press Cairo, Egypt. (In Arabic).

Almirall, M; M.Francesch; A.M. Perez-Vendrell; J. Brufan and E. Esteve-Garcia (1995). The differences in intestina viscosity produced by barley and $\beta$-glucanase alter digesta enzyme activities and ileal nutrient digestabilities more in broiler chicks than in cocks. J. of Nutr., 125:947-955.

Anderson, J.O. and R.E. Warnick (1964). Value of enzyme supplements in rations containing certain legume seed meals or gums. Poult. Sci., 43:1091-1097.

A.O.A.C. (1990). Association of Official Analytical Chemists. Official methods of analysis. $13^{\text {th }}$ Edition, Washington, DC, US.A.

Berman, E.; M. Schlicht; V.C. Moser and R.C. MacPhail (1995). A multidisciplinary approach to toxicological screening: I. Systemic toxicity. J. Toxicol. Environ. Health, 45:127.

Bochers, R. and C.W. Ackerson (1950). The nutritive value of legume seeds. J. Nutr., 41:339-345.

Brahma, T.C. and S.M. Siddiqui (1978). A preliminary study on the utilization of toasted guar meal in broiler rations. Ind. Poult. Gazette, 62:133-138.

Conner, S. (2002). Characterization of guar meal for use in poultry rations. Ph.D. Dissertation. Texas A\&M University, College Station, TX.

Curl, C.L.; K.R. Price and G.R. Fenwick (1986). Isolation and structural elucidation of a triterpenoid saponin from guar, Cyamopsis tetragonoloba. Phytochemistry, 25:2675.

Daskiran, M.; R.G. Teeter; D.W. Fodge and H.Y. Hsiao (2004). An evaluation of endo- $\beta$-D-mannanase (Hemicell) effects on broiler performance and energy use in diets varying in $\beta$-mannan content. Poult. Sci., 83:662-668.

Diwan, F.H.; I.A. Abdel-Hassan and S.T. Mohammed (2000). Effect of saponin on mortality and histopathological changes in mice. East. Mediterr, Health J., 6:345.

Duncan, D.B. (1955). Multiple range and multiple F test testbiomrtrics, 11:1-42.

Edward, C.A.; I.T. Johnson and N.W. Read (1988). Do viscous polysaccharides siow absorption by inhibitin diffusion or convection. European J. of Clinical Nutr., 42:306-312.

Ehsani, M. and M. Torki (2010). Effects of dietary inclusion of guar meal supplemented by $\beta$-mannanase on performance of laying hens, egg quality characteristics and diacritical counts of white blood cells. American J. of Animal and Veterinary Sciences, 5 (4):237-243.

Gharaei, M.A.; B. Dastar; A.H. Nameghi; G.H. Taber and M.S. Shargh (2012). Effects of guar meal with and without $\beta$-mannanase enzymes on performance and immune response of broiler chicks. Int. Res. J. Appl. Basic Sci., 3(s):2785-2793.

Hassan, S.M.; O. Gutierrez; A.U. Haq; J.A. Byrd; C.A. Bailey and A.L. Cartwright (2007). Saponin-rich extracts from quillaja, yucca, soybean, and guar differ in antimicrobial and hemolytic activities. Poult. Sci., 86:121. (Abstr.)

Hassan, S.M.; A.U. Rehman and M.F. Khalid (2012). Feeding value of guar meal and the application of enzymes in improving nutritive value for broilers. World's Poultry Science Journal, 68(2):253-268.

Hsiao, H.Y.; D.M. Anerson and N.M. Date (2006). Level of $\beta$-mannan in soybean meal. Poult. Sci., 85:1430-1432.

Jackson, M. .; K. Geronian; A. Knox; J. McNab and E. McCartney (2004). A dose-response study with the feed enzyme $\beta$-mannanase in broilers provided with corn-soybean meal based diets in the absence of antibiotic. Poult. Sci., 82:1992-1996.

Kamran, M.; T.N. Pasha; A. Mahmud and Z. Ali (2002). Effect of commercial enzyme (Natugrain) supplementation on the nutritive value and inclusion rate of guar meal in broiler rations. Inter. J. of Poult. Sci., 1(6):167-173.

Kaushal, G.P. and I.S. Bhatia (1982). A study of polyphenols in the seeds and leaves of guar (Cyamopsis tetragonoloba L. Taub). J. Sci. Food Agric., 33:461.

Khan, S. (1996). Effect of galactosidase and mannanse supplementation on nutritive value of untoasted guar meal for broilers. M.Sc thesis, Animal Nutrition Department University of Agriculture Faisalabad.

Lee, J.T.; C.A. Bailey and A.L. Cartwright (2003a). Guar meal germ and hull fractions differently affect growth performance and intestinal viscosity of broiler chickens. Poult. Sci., 82:1589-1595.

Lee, J.T.; C.A. Bailey and A.L. Cartwright (2003b). Beta-mannanase ameliorates viscosity-associated depression of growth in broiler chickens fed guar meal and hull fractions. Poult. Sci., 82:1925-1931. 
Lee, J.T.; A.S. Conner; A.U. Haq; A. Cartwright and C. Bailey (2004). Quantitative measurement of negligible trypsin inhibitor activity and nutrient analysis of guar meal fractions. J. Agric. Food Chem., 52:6492-6495.

Lee, J.T.; A.S. Conner; A.L. Cartwright and C.A. Bailey (2005). Effects of guar meal by-Product with and without B-mannanase Hemicell on Broiler Performance. Poult. Sci., 84:1261-1267.

Lee, J.T.; C.A. Bailey and A.L. Cartwright (2009). In vitro viscosity as a function of guar meal and betamannanase content of feeds. Int. J. Poult. Sci., 8(8):715-719.

Leeds, A.R.; S.S. Kang; A.G. Low and I.E. Sambrook (1980). The pig as a model for studies on the mode of action of guar gum in normal and diabetic man. The Proc. of the Nutr. Society, 39:44A.

McNaughton, J.L.; H. Hsiao; D. Anderson and D.W. Fodge (1998). Corn/ soy/ fat diets for broilers, $\beta$ mannanase and improved feed conversion. Poult. Sci., 77(Suppl. 1):153.

Mohamed, M.E. (2014). Effect of guar meal inclusion in diet on performance, bacterial population and intestinal of broiler chicks. Egyption J. Nutr. and feeds, 17(2):329-337.

Mishra, A.; S.K. Sarkar; S. Ray and S. Haldar (2013). Effects of partial replacement of soybean meal with roasted guar korma and supplementation of mannanase on performance and carcass traitsof commercial broiler chickens. Available at www.veterinaryworld.org/ Vol.6/ Sept-2013/21.pdf.

Nadeem, M.A.; A.H. Gilani; A.G. Khan and Mahr-Un-Nisa (2005). Amino Acids Availability of Poultry Feedstuffs in Pakistan. Int. J. Agri. Biol., 7(6):985-989.

Nagpal, M.L.; O.P. Agrawal and I.S. Bhatia (1971). Chemical and biological examination of guar-meal (Cyampsis tetragonoloba L.). Ind. J. Anim. Sci., 4:283-293.

Nagra, S.S. and R.S. Virk (1986). Feeding value of toasted guar meal and mustard cake for meat type chicken. Ind. J. Res. Punjab Agri.Univ., 23:122-126.

Nagra, S.S.; J.S. Chawla and A.K. Chopra (1985b). Nutritive value of ethanol extracted toasted guar meal for broiler chicks. J. Res. Punjab Agri. Univ., 22:742-746.

Nagra, S.S.; B.K. Shingari and J.S. Ichhpondni (1985a). Feeding value of guar (Cyamopsis tetragonoloba) meal to poultry. Ind. J. Poult. Sci., 20:188-193.

Patel, M.B. and J. McGinnis (1985). The effect of autoclaving and enzyme supplementation of guar meal on the performance of chicks and laying hens. Poult. Sci., 64:1148-1156.

Rajput, L.P.; S. Ramamani; M.A. Haleem and N. Sub-ramanian (1998). Chemical and biological studies on processed guar meal. Ind. J. Poult. Sci., 331:15-25.

Sagar, V.; D. Prasad; R.S. Thakur and K. Pradhan (1978). Nutritional evaluation of processed guar (Cyamopsis tetragonoloba) meal for broilers. Ind. J. Poult. Sci., 13:155-160.

SAS (1996). SAS, procedure Guid: Version b. 12Ed. "SAS Institute” Ink., Cary, NC, USA.

Salma, H. Abu Hafsa; M.M. Basyony and A.A. Hasan (2015). Effects of partial replacement of soybean meal with different levels of guar korma meal on growth performance, carcass traits and blood metabolism of broiler chickens. Asian J. of Poult. Sci. 9(3) ISSN 1819-3609 / DOI: 10.3923/ ajpsaj.2015.

Thakur, R.S. and K. Pradhan (1975a). A note on inclusion of guar meal (Gyamopsis tetragonoloba) in broiler rations. Ind. J. Anim. Sci., 45:98-102.

Thakur, R.S. and K. Pradhan (1975b). Guar meal (Cyamopsis tetragonoloba) inclusion in broiler ration. Effect on carcass yield and meat composition, Ind. J. Anim. Sci., 45:880-884.

Verma, S.V.S. and J.M. Mc-Nab (1982). Guar meal in diets for broiler chickens. Br. Poult. Sci., 23: 95 105.

Verma, S.V.S. and J.M. Mc-Nab (1984). Performance of hens fed guar meal containing diets with or without supplemental cholesterol. Ind. J. Poult. Sci., 19:245-250.

Vohra, P. and F.H. Kratzer (1965). Improvement of guar meal by enzymes. Poult. Sci., 43: 1201-1205.

Zangiabadi, H.R. and M. Torki (2010) The effect of a $\beta$-mannanase-based enzyme on growth performance and humoral immune response of broiler chickens fed diets containing graded levels of whole dates. Tropical Animal Health and Production, 42: 1209-1217. 
تأثير إحلال مستويات مختلفة من كسب الجوار مع أو بدون إضافة الإنزيمات على أداء الدجاج المحلى ( أنشاص) محمد محمد نصر الله محمد, امانى حسين والى , هبه حامد مصطفى, همت عبد العال عبد المجيد, إبراهيم محمد معوض عساف و مجدي محمد محمد عودة. معهج بحوث الإتتاج الحيوانيى, مركز البحوث الزراعية الدقى - الجيزة - مصر.

تهدف هذه الدراسة إلي تقييم الإحلال الجزئي لكسب الجوار بدلا من كسب فول الصويا في علائق الدجاج المحلى (أنشاص) على الألى

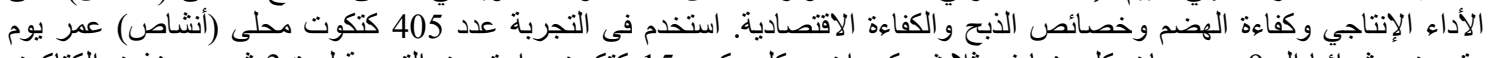

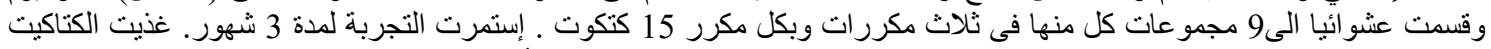

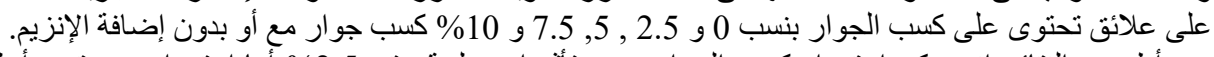

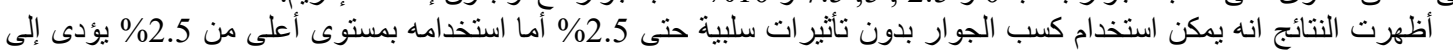

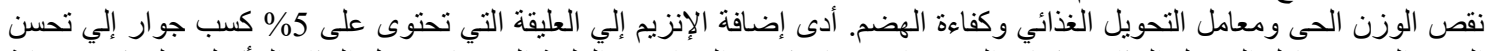

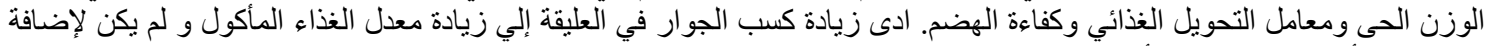

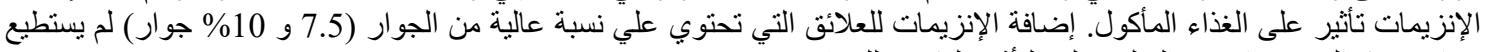

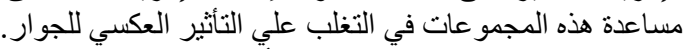

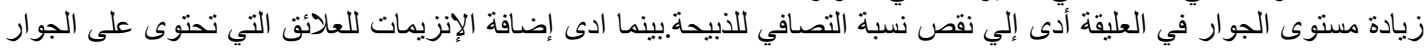

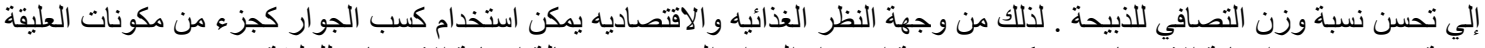
بنسبة 2.5\% بدون إضافة الإنزيمات. ويمكن رفع نسبة استخدام الجوار إلى 5\% في لاليح حالة إضافة الإنزيمات للعليقة . 